\title{
Enzymatic hydrolysis by Trichoderma reesei of diluted acid-pretreated wastepaper for bioethanol production
}

Nazia Hossain ( $\boldsymbol{\nabla}$ bristy808.nh@gmail.com )

"RMIT University" https://orcid.org/0000-0001-7925-0894

Lee Lai Hoong

Universiti Tenaga Nasional

Pranta Barua

Chittagong University of Engineering and Technology

Manzoore Elahi M Soudagar

University of Malaya: Universiti Malaya

Teuku Meurah Indra Mahlia

University of Technology Sydney

Research Article

Keywords: Acid Pretreatment, Bioethanol from Wastepaper, Enzymatic Hydrolysis

Posted Date: February 23rd, 2021

DOI: https://doi.org/10.21203/rs.3.rs-202497/v1

License: (9) This work is licensed under a Creative Commons Attribution 4.0 International License.

Read Full License 
17

18

\section{bioethanol production}

${ }^{a}$ School of Engineering, RMIT University, Melbourne VIC 3001, Australia

${ }^{b}$ Department of Mechanical Engineering, Universiti Tenaga Nasional,

Selangor 43000, Malaysia

${ }^{c}$ Department of Electrical and Electronic Engineering, Chittagong

University of Engineering \& Technology, Bangladesh

${ }^{d}$ Department of Mechanical Engineering, Faculty of Engineering, University of Malaya, 50603 Kuala Lumpur, Malaysia

eSchool of Information, Systems and Modelling, Faculty of Engineering and Information Technology, University of Technology Sydney,

NSW 2007, Australia

*Corresponding author at: Tel.: +61 480123691; E-mail address:bristy808.nh@ gmail.com (Nazia Hossain);

School of Engineering, RMIT University, 128 La Trobe Street, Melbourne, VIC 3001, Australia 


\section{Abstract}

Enzymatic hydrolysis of waste biomass for bioethanol production is considered a traditional, inexpensive, and energy-effective approach decades ago. In the present study, waste office paper was pretreated with diluted sulfuric acid $\left(\mathrm{H}_{2} \mathrm{SO}_{4}\right)$ and hydrolysed with one of the most available and cost-effective enzymes, cellulase from Trichoderma reesei, under submerged static condition. Wastepaper size was reduced to $2 \mathrm{~cm}^{2}$, blended with water and dry wetblended, and pretreated with diluted $\mathrm{H}_{2} \mathrm{SO}_{4}$. Among different concentrations $(0.5 \mathrm{M}, 1.0 \mathrm{M}$, 1.5M, 2.0M) of $\mathrm{H}_{2} \mathrm{SO}_{4}$, the maximum glucose content was obtained at $2.0 \mathrm{M} \mathrm{H}_{2} \mathrm{SO}_{4}$ at 90 min reaction time, and glucose yield was $0.11 \mathrm{~g}$ glucose $/ \mathrm{g}$ wastepaper. The cut paper, wet-blended, and acid-treated wastepaper was hydrolysed with cellulase enzyme for 2, 4, and 5 consecutive days with $5 \mathrm{mg}, 10 \mathrm{mg}, 15 \mathrm{mg}$, and $20 \mathrm{mg}$ enzyme loadings. The maximum glucose content was obtained, $9.75 \mathrm{~g} / \mathrm{l}$ after 5 days of enzymatic hydrolysis with $20 \mathrm{mg}$ enzyme loading and a glucose yield of a $0.5 \mathrm{~g}$ glucose/g wastepaper. The wastepaper hydrolysate was further fermented for 6 , 8, and 10 hours continuously with Saccharomyces cerevisiae (yeast), and at 10 hours of fermentation, the maximum glucose consumption was $0.18 \mathrm{~g}$ by yeast. Later, HPLC analysis of the fermented medium presented a strong peak of bioethanol content at $16.12 \mathrm{~min}$. Further, the distillation of bioethanol by rotary evaporator presented $0.79 \mathrm{ml}$ bioethanol/fermented solution, which indicated the conversion efficiency of $79 \%$.

Keywords: Acid Pretreatment; Bioethanol from Wastepaper; Enzymatic Hydrolysis 


\section{Introduction}

The power generation worldwide mostly relies upon fossil fuels, non-renewable energy resources comprising coal, petroleum, natural, and gas. Petroleum derivative contributes roughly $80 \%$ of energy demanded by the power and transportation sector globally (Lim \&Teong 2010). Due to the fast population growth, industrialization and urbanization, increasing energy demand, and rocketing economic development within the last decades, the energy demand reached the top worldwide, including Malaysia. In Malaysia, the vital energies accessible are coal and cokes, raw petroleum, oil-based commodities, flammable gas, and hydropower. The most recent measurement illustrated that more than $90 \%$ of them are nonrenewable energy sources, and little hydropower and biofuel have realistic applications (Lim \&Lam 2014). As a nation being developed, Malaysia's non-renewable energy source utilization pattern for as far back as 10 years showed an expanding incline (Balasbaneh et al. 2018). Consequently, petroleum product, a non-sustainable power source, is quickly diminishing and will most likely be unable to develop vitality requests.

A large portion of the essential energy assets is petroleum products in the country. They are quickly exhausted since the interest in energy is expanding because of the advancement of the economy and energy investments. Likewise, the consumption of petroleum product adds to the outflow of ozone harming substances, which is the significant reason for a dangerous atmospheric deviation (Ong et al. 2014). Among the other options, bioethanol offers a more substantial part of the ideal rules, for example, inexhaustibility, maintainability, and ecological cordial. One of the significant elements for bioethanol production is the availability of raw material. To avoid a clash with the food and feed chain, waste biomass is preferred for this purpose (Hossain et al. 2019a). Subsequently, looking for potential, inexpensive and available raw material in Malaysia for bioethanol production is a significant factor. 

decently cross-country and $1.7 \mathrm{~kg} /$ singular/day for critical metropolitan networks (Kathirvale et al. 2004). Approximately 7.34 million tons of MSW were produced in 2006, which can accumulate to 42 structures. Urbanization and industrialization are the reason for this large amount of MSW generation (Saeed et al. 2009). The principal portions of this MSW are mostly food packaging, glass, metal, paper, plastic, and others. According to Table 1, the degree of wastepaper generation increased from $6.3 \%$ in 2001 to $22.7 \%$ in the year 2010 (Chua et al. 2011). It was one of the most crucial MSW structures that appeared in Malaysia. Therefore, it is evident that the advantages of lignocellulosic biomass would be sourced from waste biomass such as wastepaper. The previous studies presented that $20 \%$ of 7.34 million tons MSW are almost squandered paper and the wastepaper is nearly 1.5 million tons. This outcome unveiled that almost $20 \%$ of MSW were generated by wastepaper. Therefore, utilizing wastepaper for bioethanol production can significantly facilitate the waste management section in Malaysia.

Table 1: Chemical combination of MSW from various experiments and reports (Chua et al.

\begin{tabular}{lccccccc}
\hline Component & $\mathbf{2 0 0 1}$ & $\mathbf{2 0 0 2}$ & $\mathbf{2 0 0 3}$ & $\mathbf{2 0 0 4}$ & $\mathbf{2 0 0 5}$ & $\mathbf{2 0 0 7}$ & $\mathbf{2 0 1 0}$ \\
\hline $\begin{array}{l}\text { Food waste \& } \\
\text { organic }\end{array}$ & 68.4 & 56.3 & 37.4 & 49.3 & 45 & 42 & 43.5 \\
\hline Mix plastic & 11.8 & 13.1 & 18.9 & 9.7 & 24 & 24.7 & 25.2 \\
\hline Mix Paper & 6.3 & 8.2 & 16.4 & 17.1 & 7 & 12.9 & 22.7 \\
\hline Textiles & 1.5 & 1.3 & 3.4 & - & - & 2.5 & 0.9 \\
\hline Rubber \& leather & 0.5 & 0.4 & 1.3 & - & - & 2.5 & - \\
\hline Wood & 0.7 & 1.8 & 3.7 & - & - & 5.7 & - \\
\hline Ferrous & 2.7 & 2.1 & 2.7 & 2 & 6 & 5.3 & 2.1 \\
\hline
\end{tabular}




\begin{tabular}{lccccccc}
\hline Glass & 1.4 & 1.5 & 2.6 & 3.7 & 3 & 1.8 & 2.6 \\
\hline Yard wastes & 4.6 & 6.9 & 3.2 & - & - & - & - \\
\hline Pampers & - & - & 5.1 & - & - & - & - \\
\hline Other & 2.1 & 8.4 & 5.3 & 18.2 & 15 & 2.6 & 1.8 \\
\hline Total & 100 & 100 & 100 & 100 & 100 & 100 & 100
\end{tabular}

For bioethanol synthesis, the type of feedstock is one of the significant concerns for the steady and persistent process. Because of Malaysia's wastepaper age, waste paper's accessibility

87 isn't a substantial issue for feedstock gracefully. Besides, the source of wastepaper from MSW is available without any economic value, facilitating the elimination of raw material cost for bioethanol production. Therefore, wastepaper can be considered one of the most suitable feedstocks for bioethanol production in the country. Wastepaper can be in several categories,

91 such as the cupboard, magazine, office paper, regular paper, and others. Table 2 presented a 92 combination of various kinds of wastepaper. Based on Table 2, every category contains approximately $50 \%-70 \%$ sugar content, which can be applied for bioethanol generation.

94 Subsequently, wastepaper can add value as a feedstock for bioethanol production (Wang et al. 95 2012).

Table 2: Composition for the different waste paper (Wang et al. 2012)

\begin{tabular}{ccccc}
\hline Percentage, \% & Newspaper & Office paper & Magazine & Cardboard \\
\hline Total carbohydrates & 65.38 & 73.39 & 50.10 & 69.35 \\
\hline ASL & 1.06 & 1.41 & 0.98 & 1.59 \\
\hline AIL & 17.08 & 4.68 & 13.85 & 14.18 \\
\hline Total lignin & 18.14 & 6.09 & 14.83 & 15.77 \\
\hline Extractives & 3.93 & 1.97 & 3.45 & 2.55 \\
\hline
\end{tabular}




\begin{tabular}{ccccc}
\hline $\mathrm{CaCO}_{3}$ & 2.13 & 8.12 & 2.63 & 4.20 \\
\hline Ash & 10.51 & 7.97 & 30.14 & 0.89
\end{tabular}

97

98

99

100

101

102

103

104

105

106

107

108

109

110

111

112

113

114

115

116

117

118

119

The availability of feedstock for bioethanol production is one of the most crucial concerns. Lignocellulosic biomass is a suitable material for the containment of its' cellulose and hemicelluloses, which can be transformed into sugar and further production of bioethanol. For the most part, lignocellulosic biomass is a horticultural build-up or strong metropolitan waste that is modest and bountiful. For instance, rice straw, void natural product pack, wastepaper, and some more (Kim 2004). In this manner, lignocellulosic biomass is appropriate as feedstock in the production process, accessibility, and cost. However, the accessibility of lignocellulosic biomass is occasional and relies upon topography. Besides, lignin's solid obstructions in lignocellulosic biomass increment the trouble for hydrolysis's mechanism, where additional pretreatment would be required. Along with that, this issue increases the production cost simultaneously. Other than that, the structure of lignocellulosic biomass undertakes significant functions in bioethanol synthesis measures. The factor incorporates cellulose crystallinity, polymerization, lignin substance, and others (Pan et al. 2006). Different studies, experiments are conducted on the production of bioethanol from waste papers. A previous study demonstrated that bioethanol could be generated from waste newspapers by extracting cellulose, and later, it was processed into sugar for bioethanol production using different bacteria. This experimental study also outlined that a maximum of $55 \%$ cellulose can be extracted to synthesize bioethanol from biological hydrolysis. The yield of bioethanol was around 7\% (v/v) (Byadgi \&Kalburgi 2016). Another experimental study on wastepaper hydrolysis evinced that waste office paper and newspaper are perfect for raw material (Annamalai et al. 2020). This study showcased that hydrolysis efficiency was $91.8 \%$ and $79.6 \%$ for office paper and newspaper, respectively, which enhanced the yield of bioethanol 
production from wastepaper. Another previous study provided a brief discussion of bioethanol production's sensitivity analysis from various waste papers considering economic feasibility. The finding represented a $25 \%$ selling price reduced in bioethanol production using sensitivity analysis considering all parameters. It also mentioned that bioethanol's selling price from the waste newspaper, office paper, and cardboard paper is competitive to petrol (Wang et al. 2013).

A previous study (Tadmourt et al. 2020) showcased the optimized acid hydrolysis of wastepaper to produce bioethanol and ensured the purity degree of $90 \%$ (v/v) (Tadmourt et al. 2020). The previous study presented a brief review of the current condition of wastepaper for bioethanol production. This review demonstrated that after demineralizing lignified waste papers, the increased content of carbohydrates and lignin was observed. In contrast to lignified waste, the demineralization of the bleached waste papers, e.g., office paper, leads to increased content only carbohydrates, mainly of cellulose. The obtained data have been delineated in Table 3 .

\begin{tabular}{lccccccccc}
\hline & \multicolumn{2}{c}{ Cellulose, \% } & \multicolumn{3}{c}{ Lignin, \% } & \multicolumn{2}{c}{ Mineral, \% } \\
& IN & DM & IN & DM & IN & DM & IN & DM \\
\hline Cardboard & 61 & 63 & 12 & 13 & 18 & 19 & 7 & 3 \\
\hline $\begin{array}{l}\text { Newspaper } \\
\text { Packaging }\end{array}$ & 38 & 50 & 15 & 18 & 21 & 26 & 19 & 4 \\
\hline paper & 60 & 73 & 11 & 8 & 7 & 12 & 20 & 3 \\
\hline $\begin{array}{l}\text { Napkins } \\
\text { Blotting paper }\end{array}$ & 58 & 78 & 6 & 10 & 4 & 5 & 29 & 4 \\
\hline
\end{tabular}


lignocellulosic biomass besides wastepaper. Previous experimental studies indicated that bioethanol from lignocellulosic waste biomass has the promising potential as an alternative fuel for fossil fuel and be sustainable green energy in the near future (Fan \&Lynd 2007, Har et al. 2013, Hossain \&Jalil 2015, Hossain et al. 2017, Petersen et al. 2009, Tappi 2002, Zhu 2006). Bioethanol from wastepaper was experimented in few previous studies on mixed wastepaper, newspapers, cardboard, or packaging paper. In contrast, this study emphasized the office paper from municipal solid waste. Besides, the previous studies of bioethanol from wastepaper were hydrolysed by different enzymes. A previous experimental study demonstrated bioethanol production from wastepaper pulp hydrolysed with xylose-fermenting Pichia stipites. But this study utilized the most available and less expensive cellulase enzyme from Trichoderma reesei.

The main objectives of this experimental study are (i) to study the reasonable reaction time and acid pretreatment for the diluted acid pretreatment of wastepapers (ii) to determine the effect of pretreatment towards enzymatic hydrolysis (iii) to assess the effect of enzyme loading to enzymatic hydrolysis (iv) to identify the glucose content released after dilute acid pretreatment and enzymatic hydrolysis and compare and (v) to measure the amount of bioethanol content from wastepaper after yeast fermentation.

\section{Materials and Methods}

The methods of this study delineated the preparation and investigation of boundaries for hydrolysis and bioethanol production from wastepaper, required materials and instruments, 


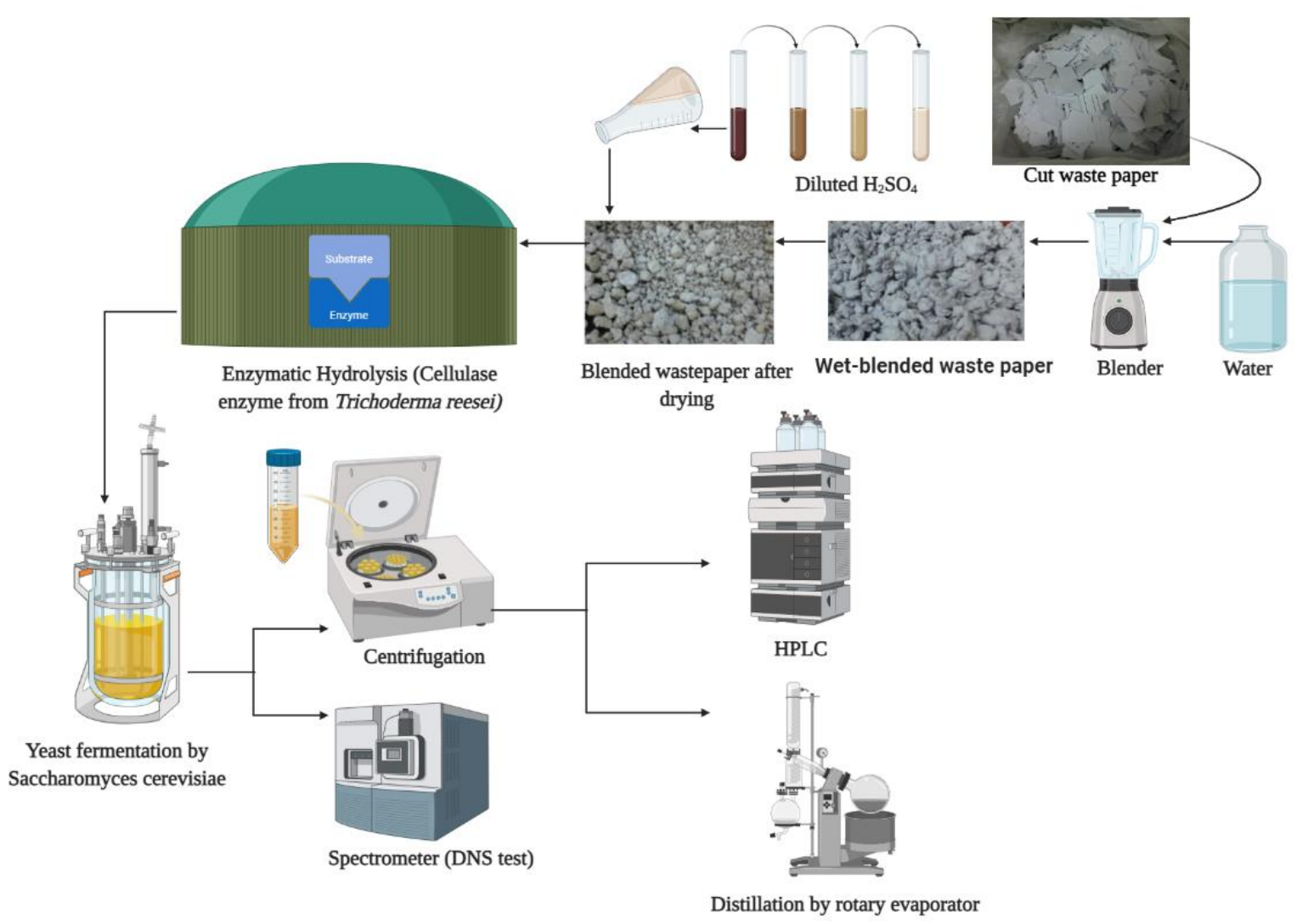

Fig. 1: Different steps of hydrolysis for bioethanol production from wastepaper (drawn by authors via BioRender.com)

\subsection{Preparation of Wastepaper}

The wastepaper (office paper) has been collected from the municipal solid waste (MSW) plant located at Klang Valley, Malaysia. Squander office paper has been collected for the experimental purpose. The collected wastepaper was cut into approximately $2 \mathrm{~cm}^{2}$. The wastepaper, and (iii) acid pre-treated wastepaper. 400g cut wastepaper was blended with distilled water. The wet-blended wastepaper was dried into a broiler around $70^{\circ} \mathrm{C}$ for 24 hours and preserved in an air-tight jar for further experiments. 
$4 \mathrm{~g}$ of three categories of wastepaper was placed into conical flasks. $100 \mathrm{ml}$ of $0.5 \mathrm{M}$ sulphuric acid $\left(\mathrm{H}_{2} \mathrm{SO}_{4}\right)$ was added to the flasks. Duplicates have been prepared, and the flask was heated in a water bath at $90^{\circ} \mathrm{C}$ for different reaction times, 30, 60, and 90 minutes, separately. The flasks were left at room temperature for cooling. $200 \mathrm{ml}$ of $0.5 \mathrm{M}$ sodium hydroxide $(\mathrm{NaOH})$ was added to the mixture to neutralize the acidic environment and shaken vigorously. The acid pretreatment was also conducted for $1.0 \mathrm{M}, 1.5 \mathrm{M}$, and $2.0 \mathrm{M}$ sulphuric acid and sodium hydroxide separately. The supernatant for each sample was assembled into a rotator tube. The axis tubes were centrifuged at $4000 \mathrm{rpm}$ for 10 minutes. The supernatants proceeded for the 3,5-dinitrosalicylic acid (DNS) test. Atomic absorbance spectrometer (AAS) was done to determine glucose content at wavelength A540. The optical density (OD) for each sample

$\left(\mathrm{KH}_{2} \mathrm{PO}_{4}\right)$, and $0.2 \mathrm{~g}$ ammonium chloride $\left(\mathrm{NH}_{4} \mathrm{Cl}\right)$ were mixed with $100 \mathrm{ml}$ distilled water into

\subsection{Enzymatic Hydrolysis by Trichoderma reesei}

Cellulase enzyme produced by Trichoderma reesei has been obtained from Sigma Aldrich, United States. $2 \mathrm{~g}$ of diluted acid pre-treated wastepaper was placed into conical flasks. $100 \mathrm{ml}$ of sodium acetate $\left(\mathrm{C}_{2} \mathrm{H}_{3} \mathrm{NaO}_{2}\right)$ solution was added to each solution to maintain the neutral pH. 5mg, $10 \mathrm{mg}, 15 \mathrm{mg}$, and $20 \mathrm{mg}$ of cellulase enzyme has been loaded into separate flasks, and the flasks were set at incubator shaker for continuously 2,4 , and 5 days at $37^{\circ} \mathrm{C}$ and $100 \mathrm{rpm}$.

\subsection{Yeast Preparation and Fermentation of Hydrolysate}

2.4.1. Yeast Preparation

$10 \mathrm{~g}$ of D-glucose monohydrate $\left(\mathrm{C}_{6} \mathrm{H}_{14} \mathrm{O}_{7}\right), 0.4 \mathrm{~g}$ of potassium dihydrogen phosphate a conical flask. The mixture was mixed vigorously with a magnetic stirrer, then sealed with 
cotton and aluminum foil. The mixture was sterilized for $15 \mathrm{~min}$ in an autoclave. Then $1 \mathrm{~g}$ yeast (Saccharomyces cerevisiae) extract was added into the solution under a laminar hood. The flask was placed into an incubator shaker at $37^{\circ} \mathrm{C}$ and $100 \mathrm{rpm}$. Samples were taken for the first 6 hours and alternative 2 hours until 10 hours and centrifuged. After centrifugation, the supernatants tested with DNS test for glucose and OD for glucose content and yeast were obtained by AAS at wavelengths, A540 and A640nm, respectively.

\subsubsection{Fermentation of Hydrolysate}

After enzymatic hydrolysis, the enzymatic hydrolysate was filtered and centrifuged. $15 \mathrm{~g}$ of filtered hydrolysate was mixed with the yeast broth (10:1 ratio of filtrate and yeast) into a flask, and a duplicate was prepared. $\mathrm{pH}$ of the mixture has been maintained at 5.5 by adding $\mathrm{H}_{2} \mathrm{SO}_{4}$ and $\mathrm{NaOH}$. The flasks were sealed with cotton and aluminum foil and autoclaved for $15 \mathrm{~min}$. The flasks were set into an incubator shaker at $37^{\circ} \mathrm{C}$ and $100 \mathrm{rpm}$ for 2 and 4 days fermentation. After fermentation, the solution was centrifuged and tested with DNS test for glucose, and OD for glucose content was obtained by AAS at wavelengths, A540.

\subsection{HPLC analysis and Distillation}

The sample after fermentation was taken for high-performance liquid chromatography (HPLC) test for bioethanol analysis. SUPELCOGEL C-610H, 30cm x 7.8mm column (SigmaAldrich Co., United States) was for HPLC analysis. The column temperature was $80^{\circ} \mathrm{C}$, and 5 $\mathrm{mM}$ sulfuric acid ( $\mathrm{pH} 2.2$ unadjusted) was prepared as the mobile phase. The flow rate was $1.2 \mathrm{ml} / \mathrm{min}$, and the injection amount was $25 \mu \mathrm{l}$ for the HPLC test. The bioethanol content was tested by the standard method. Due to the presence of bioethanol in the fermented sample, the sample solution was distilled by using a rotary evaporator to obtain the bioethanol. For the distillation process, the heating temperature in the rotary evaporator was set in between 65$75^{\circ} \mathrm{C} .100 \mathrm{ml}$ of the fermented solution was placed into the rotary evaporator flask. The vacuum 
pressure was set with $0.8 \mathrm{kPa}$. The distillation process was conducted around $40 \mathrm{~min}$ under vacuum conditions. After distillation, bioethanol was measured by measuring cylinder.

\section{Results and Discussions}

\subsection{Diluted Acid Pretreatment}

Glucose yield of diluted acid pretreatment was obtained by OD using the standard method, while the actual glucose yield was calculated due to eliminating dilution from real glucose obtainment. Actual glucose yield was calculated by Eq.1.

$$
\text { Actual glucose yield }=\frac{\text { optical density }}{5.0785} \times 20
$$

According to Table 4, glucose yield increased with the increase of reaction time for all acid concentration. Among different acid concentrations, the glucose yield of pre-treated wastepaper increased with the increase of concentration. Higher glucose yield represents that the pretreatment is more effective to the wastepaper because glucose is produced due to cellulose's accessibility and that is the reason for conducting pre-treatment. Table 4 also demonstrated no reduction of glucose as both parameters increases. Therefore, it was evident that there was no glucose degradation within these parameter values, and there will be no formation of inhibitors for enzymatic hydrolysis. Thus, the operating condition was within the acceptable range where pretreatment is efficient for accessibility of enzymatic hydrolysis to cellulose. The maximum actual glucose yield was obtained as $4.50 \mathrm{~g} / \mathrm{l}$ at $2.0 \mathrm{M} \mathrm{H}_{2} \mathrm{SO}_{4}$ concentration at 90min reaction time. The actual glucose yield, $4.5053 \mathrm{~g} / \mathrm{l}$, was obtained from $4 \mathrm{~g}$ of wastepaper in $100 \mathrm{ml}$ of $\mathrm{H}_{2} \mathrm{SO}_{4}$. The conversion calculation has been presented in Eq.2 and Eq.3.

$$
\frac{4 g \text { wastepaper }}{100 \mathrm{ml}} \times \frac{1000 \mathrm{ml}}{1 \mathrm{l}}=\frac{40 \mathrm{~g}}{l}(\text { Eq. } 2)
$$



minutes is $11.26 \%$. In other words, $1 \mathrm{~g}$ of wastepaper can produce $0.11 \mathrm{~g}$ of glucose.

Table 4: Glucose yield obtained from dilute acid pre-treatment

\begin{tabular}{|c|c|c|c|c|}
\hline $\begin{array}{c}\mathrm{H}_{2} \mathrm{SO}_{4} \\
\text { Concentration } \\
\text { (M) }\end{array}$ & $\begin{array}{c}\text { Time } \\
\text { (Minutes) }\end{array}$ & $\begin{array}{l}\text { Optical } \\
\text { density }\end{array}$ & $\begin{array}{c}\text { Glucose } \\
\text { Yield } \\
(\mathrm{g} / \mathrm{L})\end{array}$ & $\begin{array}{c}\text { Actual } \\
\text { Glucose } \\
\text { Yield } \\
\text { (g/L) }\end{array}$ \\
\hline \multirow[t]{3}{*}{0.5} & 30 & 0.004 & 0.008 & 0.0158 \\
\hline & 60 & 0.121 & 0.238 & 0.4765 \\
\hline & 90 & 0.300 & 0.591 & 1.1815 \\
\hline \multirow[t]{3}{*}{1.0} & 30 & 0.131 & 0.258 & 0.5159 \\
\hline & 60 & 0.402 & 0.792 & 1.5831 \\
\hline & 90 & 0.553 & 1.089 & 2.1778 \\
\hline \multirow[t]{3}{*}{1.5} & 30 & 0.433 & 0.853 & 1.7052 \\
\hline & 60 & 0.736 & 1.449 & 2.8985 \\
\hline & 90 & 0.940 & 1.851 & 3.7019 \\
\hline \multirow[t]{3}{*}{2.0} & 30 & 0.579 & 1.140 & 2.2802 \\
\hline & 60 & 0.847 & 1.668 & 3.3356 \\
\hline & 90 & 1.144 & 2.253 & 4.5053 \\
\hline
\end{tabular}

Table 5 showed the glucose yield for different enzyme loading in enzymatic hydrolysis.

249 The OD of each sample collected from the $2^{\text {nd }}, 4^{\text {th, }}$ and $5^{\text {th }}$ day was obtained through a spectrometer, and the glucose yield was calculated using the linear equation from the glucose 
standard curve, $y=5.0785 x$. The dilution factors used for the $2^{\text {nd }}, 4^{\text {th, }}$ and $5^{\text {th }}$ day were 10,20 ,

252

253

254

255

256

257

258

259

260

261

262

263

264

265

266

267

\begin{tabular}{|c|c|c|c|}
\hline Time & Enzyme Loading (mg) & Optical Density & Glucose Yield (g/L) \\
\hline \multirow{3}{*}{ Day 2 } & 5 & 1.479 & 2.9123 \\
\cline { 2 - 4 } & 10 & 1.826 & 3.5955 \\
\cline { 2 - 4 } & 15 & 2.329 & 4.5860 \\
\cline { 2 - 4 } & 20 & 2.439 & 4.8026 \\
\hline Day 4 & 5 & 0.906 & 3.5680 \\
\hline
\end{tabular}
and 25, respectively. Eq. 4 is used to calculate the glucose yield of each sample.

$$
Y_{\text {glucose }}=\frac{O D}{5.0785} \times D_{f} \quad(\text { Eq.4) }
$$

Where, $Y_{\text {glucose }}=$ Yield of glucose, $\mathrm{OD}=$ Optical Density, $\mathrm{D}_{\mathrm{f}}=$ Dilution factor

The glucose yields of enzymatic hydrolysis with a higher dose of enzyme loading were always higher at any day of hydrolysis. This result presented that the higher enzyme loading dosage was, the faster enzymatic hydrolysis produced glucose from the cellulosic wastepaper. However, the glucose yields also showed that glucose yield speeded up faster till $15 \mathrm{mg}$ of enzyme loading, while after $15 \mathrm{mg}$ enzyme loading, the glucose yield did not speed up significantly. The difference between glucose contents at $15 \mathrm{mg}$ and $20 \mathrm{mg}$ loading is very slight for each day. Hence, it was crystal clear that the ratio between substrate loading to enzyme loading, 2:15 was the optimum ratio for faster glucose yield. Table 5 also showed that the glucose yield for $20 \mathrm{mg}$ enzyme loading is almost constant for day 4 and day 5 but not for another enzyme loading. Thus, the results manifested that the enzymatic hydrolysis was completed within this time, and maximum glucose yield has been obtained. The maximum glucose yield was $9.76 \mathrm{~g} / \mathrm{L}$, which was around $50 \%$ from acid pre-treated wastepaper or $1 \mathrm{~g}$ of acid pretreated wastepaper produced $0.5 \mathrm{~g}$ of glucose.

Table 5: Glucose yield for different enzyme loading of enzymatic hydrolysis 


\begin{tabular}{|c|c|c|c|}
\hline \multirow{4}{*}{} & 10 & 1.826 & 7.1911 \\
\cline { 2 - 4 } & 15 & 2.329 & 9.1720 \\
\cline { 2 - 4 } & 20 & 2.439 & 9.6052 \\
\hline \multirow{3}{*}{ Day 5 } & 5 & 0.746 & 3.6723 \\
\cline { 2 - 4 } & 10 & 1.545 & 7.6056 \\
\cline { 2 - 4 } & 15 & 1.747 & 8.6000 \\
\cline { 2 - 4 } & 20 & 1.982 & 9.7568 \\
\hline
\end{tabular}

Table 6 presented the glucose yield for different categories of wastepaper of enzymatic hydrolysis. The result showed that the glucose yield of enzymatic hydrolysis for acid pretreated wastepaper is much higher than the cut and wet-blended wastepaper. Acid pre-treatment was proven to have a significant effect on the glucose yield of enzymatic hydrolysis. The glucose yield for acid pre-treated wastepaper was around $15 \%$ of total cellulose, while the other wastepaper categories presented less than $1 \%$ of total cellulose. However, wet blending as pre-treatment of wastepaper has no effect on enzymatic hydrolysis outcome even compared with wastepaper that was cut into smaller pieces only. Despite that, wet blending was effective in improving the outcomes of acid pre-treatment.

Table 6: Glucose yield for different categories of wastepaper of enzymatic hydrolysis

\begin{tabular}{ccccc}
\hline $\begin{array}{c}\text { Categories of } \\
\text { wastepaper }\end{array}$ & Time (day) & Optical Density & $\begin{array}{c}\text { Glucose Yield } \\
(\mathbf{g} / \mathbf{L})\end{array}$ & $\begin{array}{c}\text { Percentage of } \\
\text { Glucose Yield } \\
(\%)\end{array}$ \\
\hline Cut wastepaper & 2 & 0.142 & 0.2796 & 1.40 \\
\cline { 2 - 5 } & 4 & 0.013 & 0.0512 & 0.26 \\
\cline { 2 - 5 } Wet-blended & 5 & 0.033 & 0.1624 & 0.81 \\
\cline { 2 - 5 } wastepaper & 2 & 0.005 & 0.0985 & 0.49 \\
\cline { 2 - 5 } & 4 & 0.008 & 0.0315 & 0.16 \\
\hline
\end{tabular}




\begin{tabular}{ccccc}
\hline Acid pre-treated & 2 & 1.479 & 2.9123 & 14.56 \\
\cline { 2 - 5 } wastepaper & 4 & 0.906 & 3.5680 & 17.84 \\
\cline { 2 - 5 } & 5 & 0.746 & 3.6723 & 18.36
\end{tabular}

\subsection{Fermentation of Hydrolysate}

The fermentation of hydrolysate was conducted for continuous 6, 8, and 10 hours. Fig.

2 presented the curve for OD for yeast and glucose during yeast fermentation. Based on Fig.

2, the glucose content decreased with time while $S$. cerevisiae (yeast) cell increased continuously. This outcome complied with the theoretical approach of glucose consumption by yeast cells and bioethanol and carbon-di-oxide production. Therefore, the result presented the fermentation has been successfully performed. Table 7 showed the glucose content after fermentation. The glucose yield from pretreatment and enzymatic hydrolysis is lower than the glucose content after diluted acid pretreatment and enzymatic hydrolysis, $10 \%$ of blended wastepaper, and $50 \%$ of acid-treated wastepaper. This situation may occur due to the high substrate loading compared with them since the substrate loading is one factor that significantly affects glucose yield. The sample wastepaper used includes different types of paper that may contain different amounts of glucose inside. The consumption of glucose is $0.0069 \mathrm{~g}$ for pretreatment and $0.180 \mathrm{~g}$ for enzymatic hydrolysis during 10 hours of fermentation, respectively. 


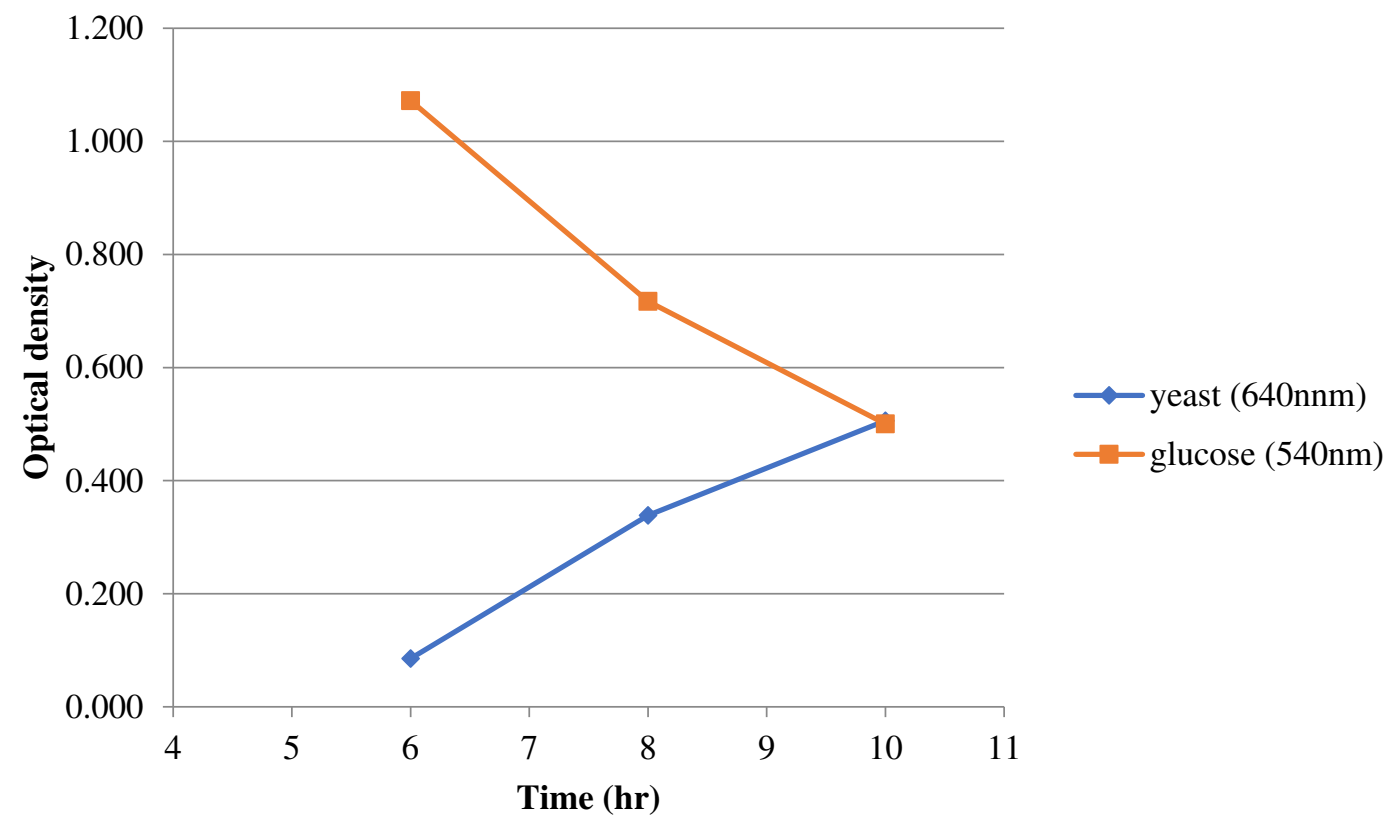

299

Fig. 2: Optical densities of yeast and glucose for yeast fermentation

Table 7: Glucose consumed after fermentation

\begin{tabular}{|c|c|c|c|c|c|c|c|c|}
\hline \multirow{2}{*}{$\begin{array}{l}\text { Glucose } \\
\text { source }\end{array}$} & \multicolumn{3}{|c|}{ Initial } & \multicolumn{3}{|c|}{ Final } & \multirow{2}{*}{$\begin{array}{c}\text { Differenc } \\
\text { e } \\
(\mathrm{g} / \mathrm{L})\end{array}$} & \multirow{2}{*}{$\begin{array}{c}\text { Glucose } \\
\text { consume } \\
\text { d } \\
\text { (g) }\end{array}$} \\
\hline & $\begin{array}{l}\text { Optica } \\
1 \\
\text { densit } \\
y\end{array}$ & $\begin{array}{l}\text { Dilutio } \\
n \\
\text { factor }\end{array}$ & $\begin{array}{c}\text { Glucos } \\
\text { e yield } \\
(\mathrm{g} / \mathrm{L})\end{array}$ & $\begin{array}{c}\text { Optica } \\
1 \\
\text { densit } \\
y\end{array}$ & $\begin{array}{l}\text { Dilutio } \\
n \\
\text { factor }\end{array}$ & $\begin{array}{c}\text { Glucos } \\
\text { e yield } \\
(\mathrm{g} / \mathrm{L})\end{array}$ & & \\
\hline $\begin{array}{c}\text { Pre- } \\
\text { treatmen } \\
\underset{t}{t}\end{array}$ & 0.109 & 20 & 0.4393 & 0.094 & 20 & 0.3702 & 0.0691 & 0.0069 \\
\hline $\begin{array}{l}\text { Enzymati } \\
\text { c } \\
\text { hydrolysi } \\
\text { s }\end{array}$ & 1.934 & 10 & 3.8082 & 0.204 & 50 & 2.0085 & 1.7997 & 0.1800 \\
\hline
\end{tabular}


Fig. 3(a) presented HPLC generated graph for fermentation using glucose from pre-

307 treatment HPLC generated a graph for fermentation using glucose from pre-treatment. From

308 Fig. 3(a), the vertex at 16.45 minutes was the bioethanol content produced inside the 309 fermentation of glucose from pre-treatment. Fig. 3(b) zoomed out the peak of bioethanol 310 content at 16.125 minutes during fermentation glucose from enzymatic hydrolysis. Thus, the 311 HPLC graphs showed that the fermentation process was successful, and the fermented solution 312 contained bioethanol.

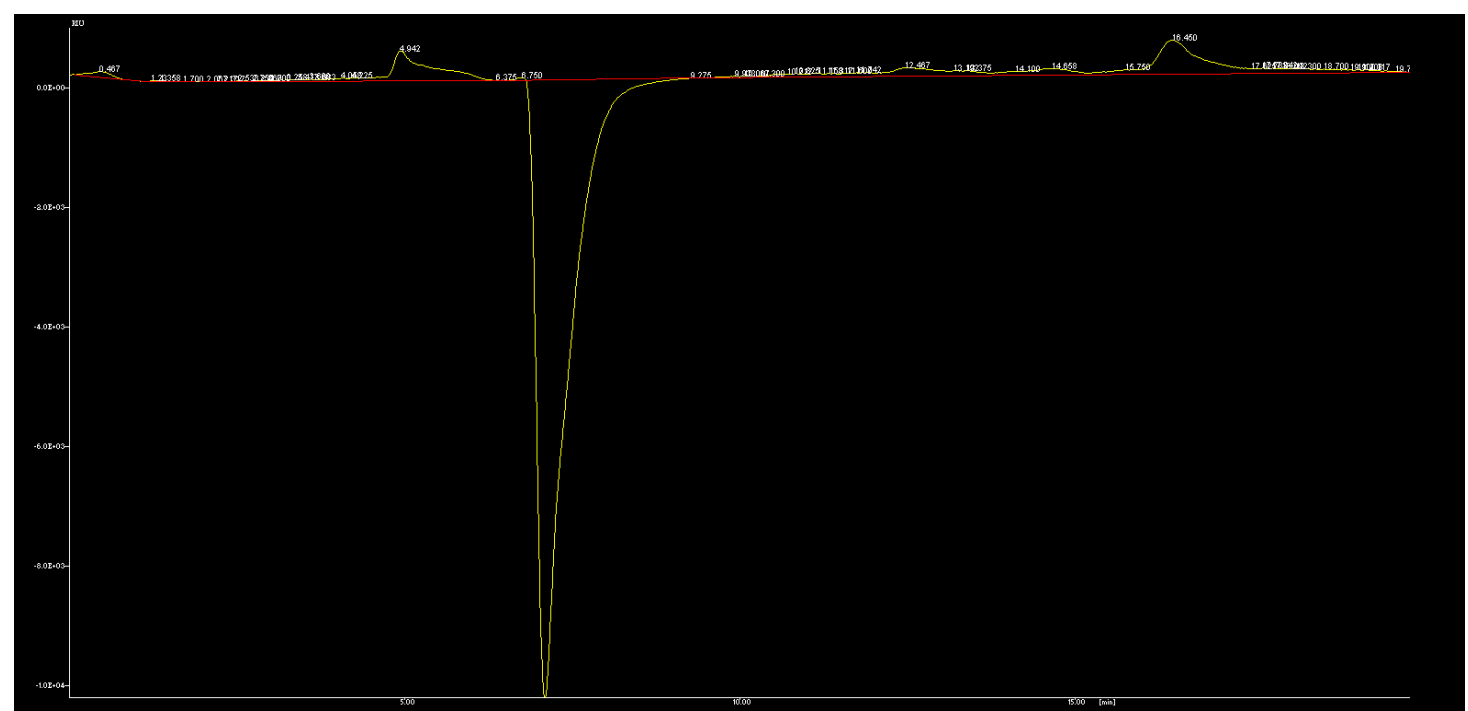

Fig. 3(a) : HPLC generated graph for fermentation using glucose from enzymatic hydrolysis

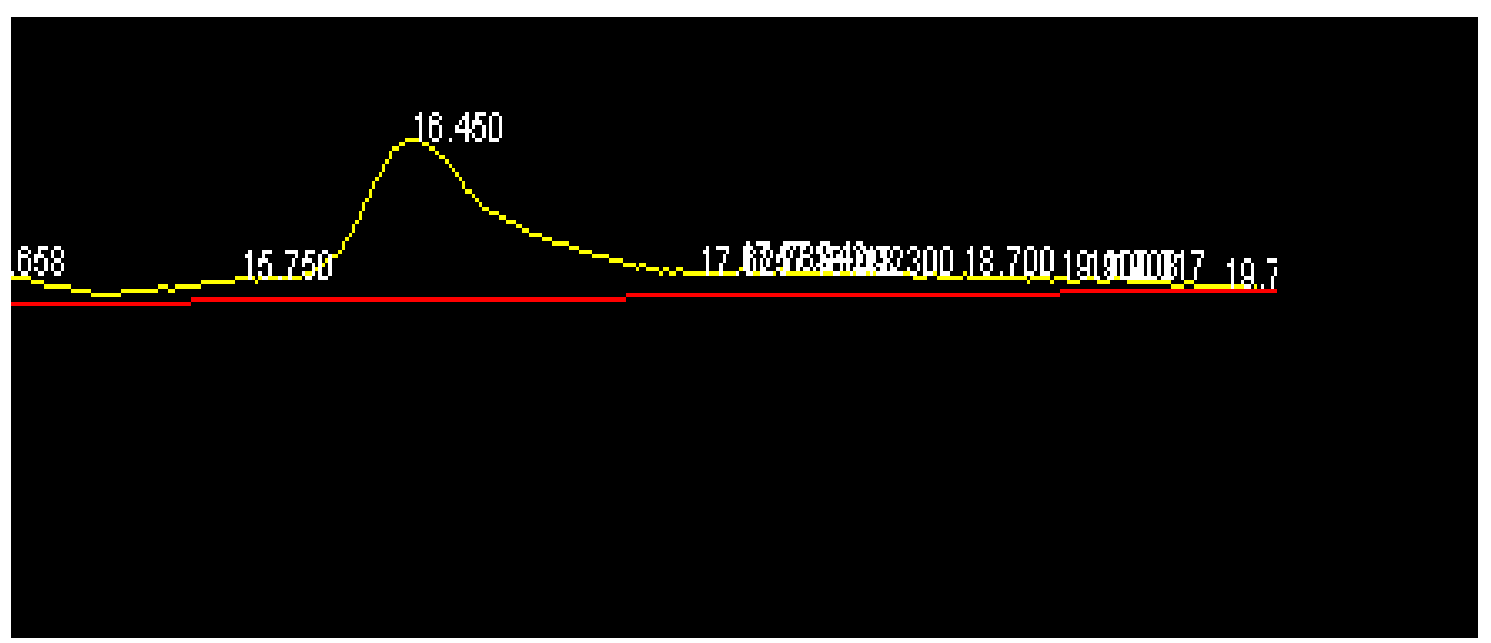


Fig. 3(b): Zoom in ethanol curve from HPLC for fermentation using glucose from enzymatic hydrolysis

Due to bioethanol in the fermented solution, the solution has been distilled by a rotary evaporator, and bioethanol was obtained. $79 \mathrm{ml}$ of distilled bioethanol has been obtained from $100 \mathrm{ml}$ of total fermented solution. Therefore, the bioethanolic yield was $79 \%$ or $0.79 \mathrm{ml}$ bioethanol $/ \mathrm{ml}$ fermented solution. The bioethanol content obtained in this study is very high compared to plant-based biomass such as agricultural and forest residue and other municipal solid waste, probably due to the very low content of lignin presence in wastepaper while most of the biomass contains high lignin content (Dubey et al. 2012, Hossain \&Jalil 2015, Hossain et al. 2019b).

\section{Conclusions}

This experimental study explored the chemical pretreatment (diluted $\mathrm{H}_{2} \mathrm{SO}_{4}$ ) of wastepaper. The delignification performed by the acid pretreatment significantly improved the glucose yield compared to the untreated and wet-blended wastepaper. A high amount of glucose content has been released from treated wastepaper during enzymatic hydrolysis in response to the cellulase enzyme from Trichoderma reesei. The amount of enzyme loading played a vital role in obtaining the optimum and maximum glucose yield. The hydrolysate produced by enzymatic hydrolysis was utilized via fermentation by the presence of $\mathrm{S}$. cerevisiae (yeast) for bioethanol production. With a longer period of fermentation, maximum glucose consumption was observed by the yeast cells. HPLC analysis of fermented medium confirmed the presence of bioethanol content, and distillation of the fermented medium identified very high bioethanol conversion efficiency. Hence, the effectiveness of diluted acid pretreatment and enzymatic hydrolysis by cellulase from Trichoderma reesei for the efficient 
saccharification of cellulosic wastepaper can be concluded. The high bioethanol conversion

341 efficiency from wastepaper via this approach can be recommended further to augment bioethanol generation. Therefore, this method is recommended for comprehensive technoeconomic and life-cycle assessments for commercial scale applications in the future.

\section{Declarations}

Ethics approval and consent to participate

347 The facts and views in the manuscript are solely ours, and we are totally responsible for

348 authenticity, validity, and originality. We also declare that this manuscript is our original work, and we have not copied from anywhere else. There is no plagiarism in my manuscript.

\section{Consent for publication}

351 We undertake and agree that the manuscript submitted to your journal has not been published 352 elsewhere and has not been simultaneously submitted to other journals.

\section{Competing interests}

354 The authors declare no conflict of interest.

355 Availability of data and materials

356 The data that support the findings of this study are available from the corresponding author, 357 Nazia Hossain, upon reasonable request.

$358 \quad$ Funding

359 No funding to declare.

\section{Credit Authorship Contribution Statement}

Nazia Hossain: Conceptualization, Methodology, Data Curation, Interpretation, Software and 
Writing- Original Draft, Pranta Barua: Writing- Review and Editing, Manzoore Elahi M

Soudagar: Writing-Review and Editing, Teuku Meurah Indra Mahlia- Supervision.

\section{References}

Annamalai N, Al Battashi H, Anu SN, Al Azkawi A, Al Bahry S, Sivakumar N (2020): Enhanced bioethanol production from waste paper through separate hydrolysis and fermentation. Waste and Biomass Valorization 11, 121-131

Balasbaneh AT, Marsono AKB, Khaleghi SJ (2018): Sustainability choice of different hybrid timber structure for low medium cost single-story residential building: Environmental, economic and social assessment. Journal of Building Engineering 20, 235-247

Byadgi SA, Kalburgi P (2016): Production of bioethanol from waste newspaper. Procedia Environmental Sciences 35, 555-562

Chua K, Sahid EJM, Leong Y (2011): Sustainable municipal solid waste management and GHG abatement in Malaysia. ST-4: Green \& Energy Management 4, 1-8

Dubey AK, Gupta P, Garg N, Naithani S (2012): Bioethanol production from waste paper acid pretreated hydrolyzate with xylose fermenting Pichia stipitis. Carbohydrate Polymers $88,825-829$

Fan Z, Lynd LR (2007): Conversion of paper sludge to ethanol. I: Impact of feeding frequency and mixing energy characterization. Bioprocess and biosystems engineering 30, 27-34

Har C-L, Hii S-L, Yong C-K, Siew S-P (2013): Statistical screening of factors affecting production of fermentable sugars from sugarcane bagasse under solid-state conditions. BioResources 8, 4546-4562

Hossain N, Jalil R (2015): Sugar and bioethanol production from oil palm trunk (OPT). Asia Pacific Journal of Energy and Environment 2, 81-84 
Hossain N, Zaini JH, Mahlia T (2017): A review of bioethanol production from plant-based waste biomass by yeast fermentation. International Journal of Technology 8, 5-18

Hossain N, Mahlia TMI, Zaini J, Saidur R (2019a): Techno-economics and Sensitivity Analysis of Microalgae as Commercial Feedstock for Bioethanol Production. Environmental Progress \& Sustainable Energy 38, 13157

Hossain N, Razali AN, Mahlia TMI, Chowdhury T, Chowdhury H, Ong HC, Shamsuddin AH, Silitonga AS (2019b): Experimental investigation, techno-economic analysis and environmental impact of bioethanol production from Banana stem. Energies 12, 3947

Ioelovich M (2014): Waste paper as promising feedstock for production of biofuel. Journal of Scientific Research and Reports, 905-916

Kathirvale S, Yunus MNM, Sopian K, Samsuddin AH (2004): Energy potential from municipal solid waste in Malaysia. Renewable energy 29, 559-567

Kim T 2004: Bioconversion of lignocellulosic material into ethanol: pretreatment, enzymatic hydrolysis, and ethanol fermentation

Lim S, Teong LK (2010): Recent trends, opportunities and challenges of biodiesel in Malaysia: an overview. Renewable and Sustainable Energy Reviews 14, 938-954

Lim X-L, Lam W-H (2014): Public acceptance of marine renewable energy in Malaysia. Energy Policy 65, 16-26

Ong HC, Masjuki HH, Mahlia TMI, Silitonga AS, Chong WT, Yusaf T (2014): Engine performance and emissions using Jatropha curcas, Ceiba pentandra and Calophyllum inophyllum biodiesel in a CI diesel engine. Energy 69, 427-445

Pan X, Gilkes N, Saddler JN (2006): Effect of acetyl groups on enzymatic hydrolysis of cellulosic substrates. Holzforschung 60, 398-401 
412 Petersen MØ, Larsen J, Thomsen MH (2009): Optimization of hydrothermal pretreatment of

413

414

415

416

417

418

419

420

421

422

423

424

425

426

427

428

429

430

431

432

433

434

435

436

437 0

32 wheat straw for production of bioethanol at low water consumption without addition of chemicals. Biomass and Bioenergy 33, 834-840

Saeed MO, Hassan MN, Mujeebu MA (2009): Assessment of municipal solid waste generation and recyclable materials potential in Kuala Lumpur, Malaysia. Waste management 29, 2209-2213

Tadmourt W, Khiari K, Boulal A, Tarabet L (2020): Waste paper valorization for bioethanol production: Pretreatment and acid hydrolysis optimization. Energy Sources, Part A: Recovery, Utilization, and Environmental Effects, 1-20

Tappi T (2002): 211 om-02. Ash in wood, pulp, paper and paperboard: Combustion at 525。 C. TAPPI test methods 5

Wang L, Templer R, Murphy RJ (2012): High-solids loading enzymatic hydrolysis of waste papers for biofuel production. Applied Energy 99, 23-31

Wang L, Sharifzadeh M, Templer R, Murphy RJ (2013): Bioethanol production from various waste papers: economic feasibility and sensitivity analysis. Applied energy 111, 11721182

Zhu L 2006: Fundamental study of structural features affecting enzymatic hydrolysis of lignocellulosic biomass, Texas A\&M University 


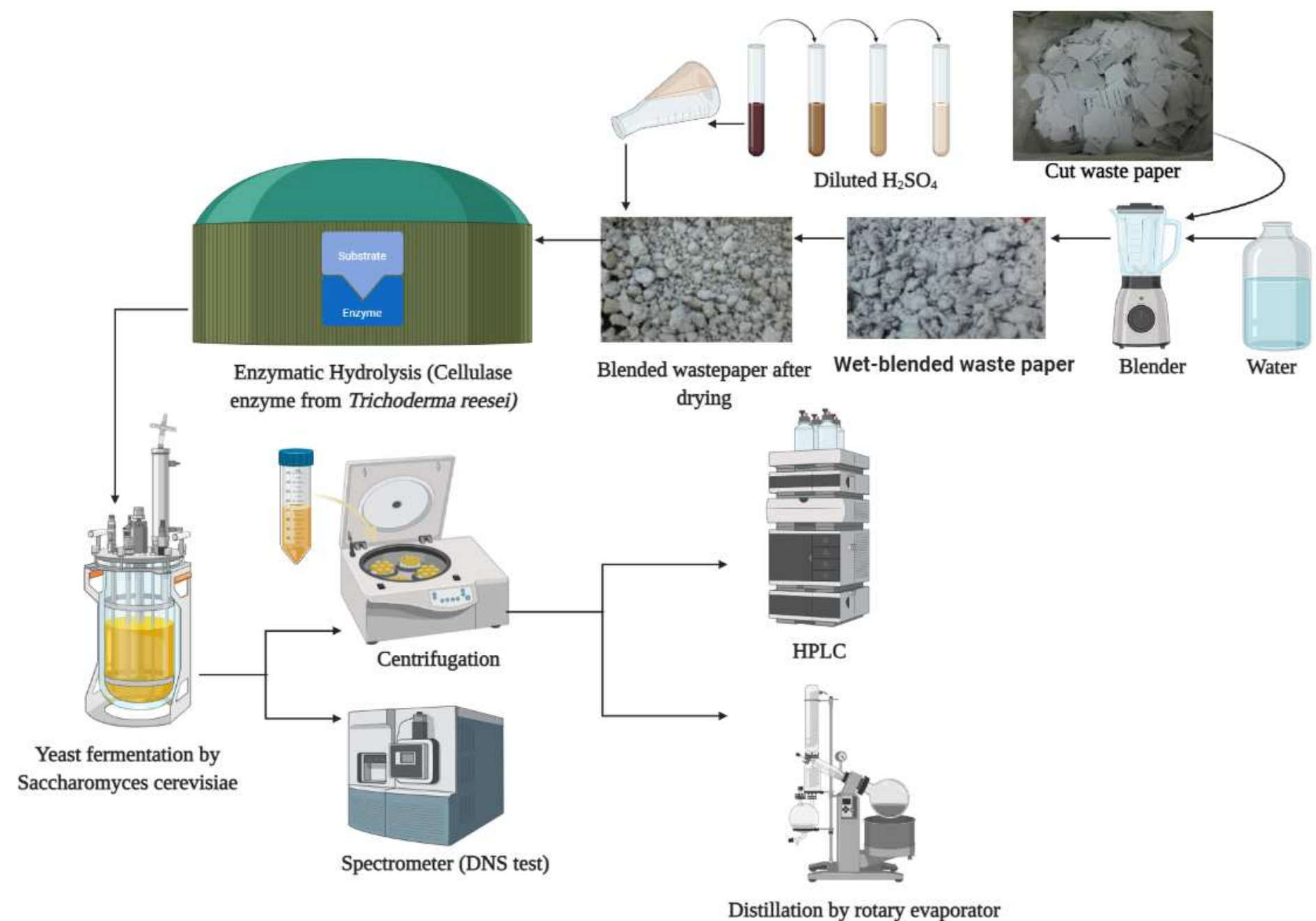

Created in BioRender.com bio

\section{Figure 1}

Different steps of hydrolysis for bioethanol production from wastepaper (drawn by authors via BioRender.com) 


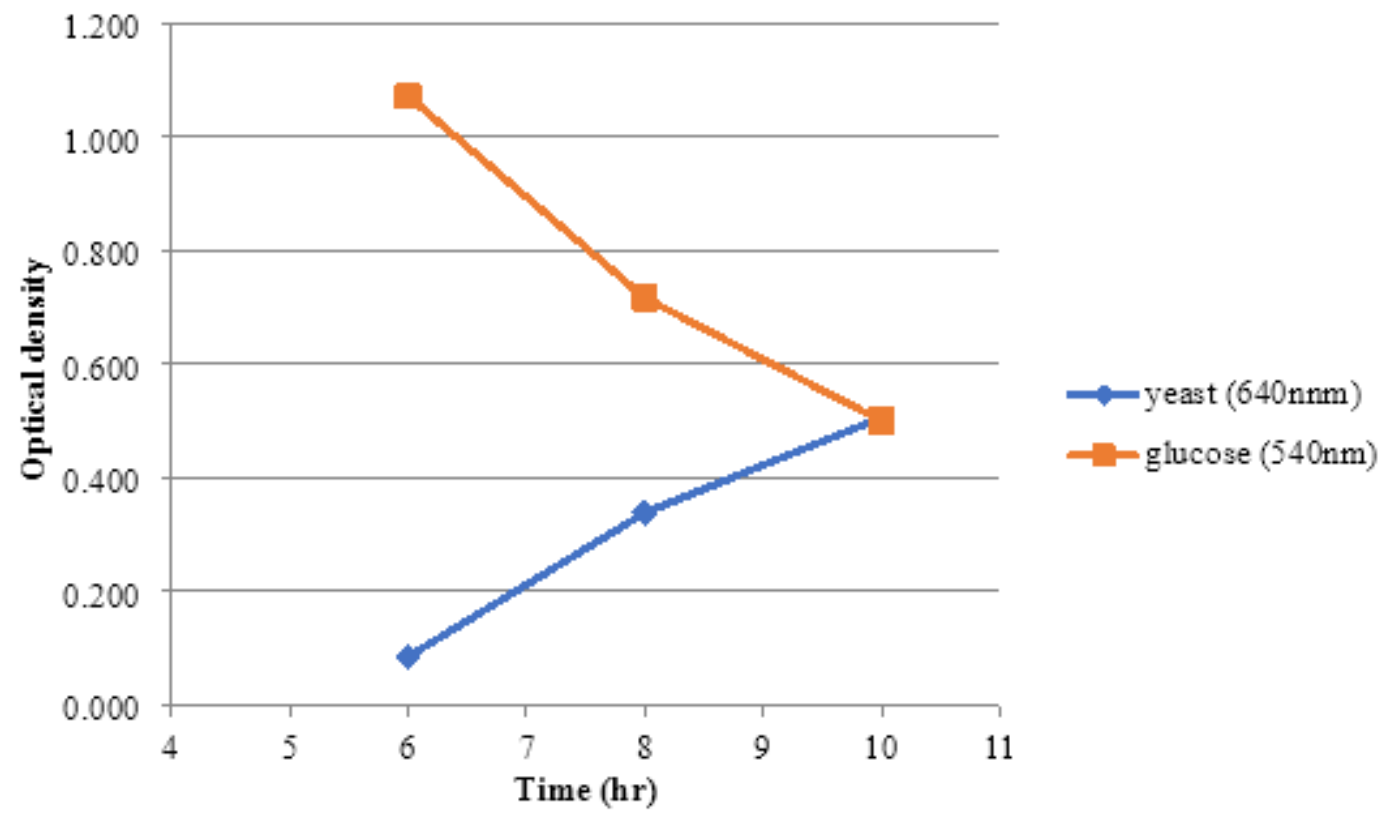

Figure 2

Optical densities of yeast and glucose for yeast fermentation 


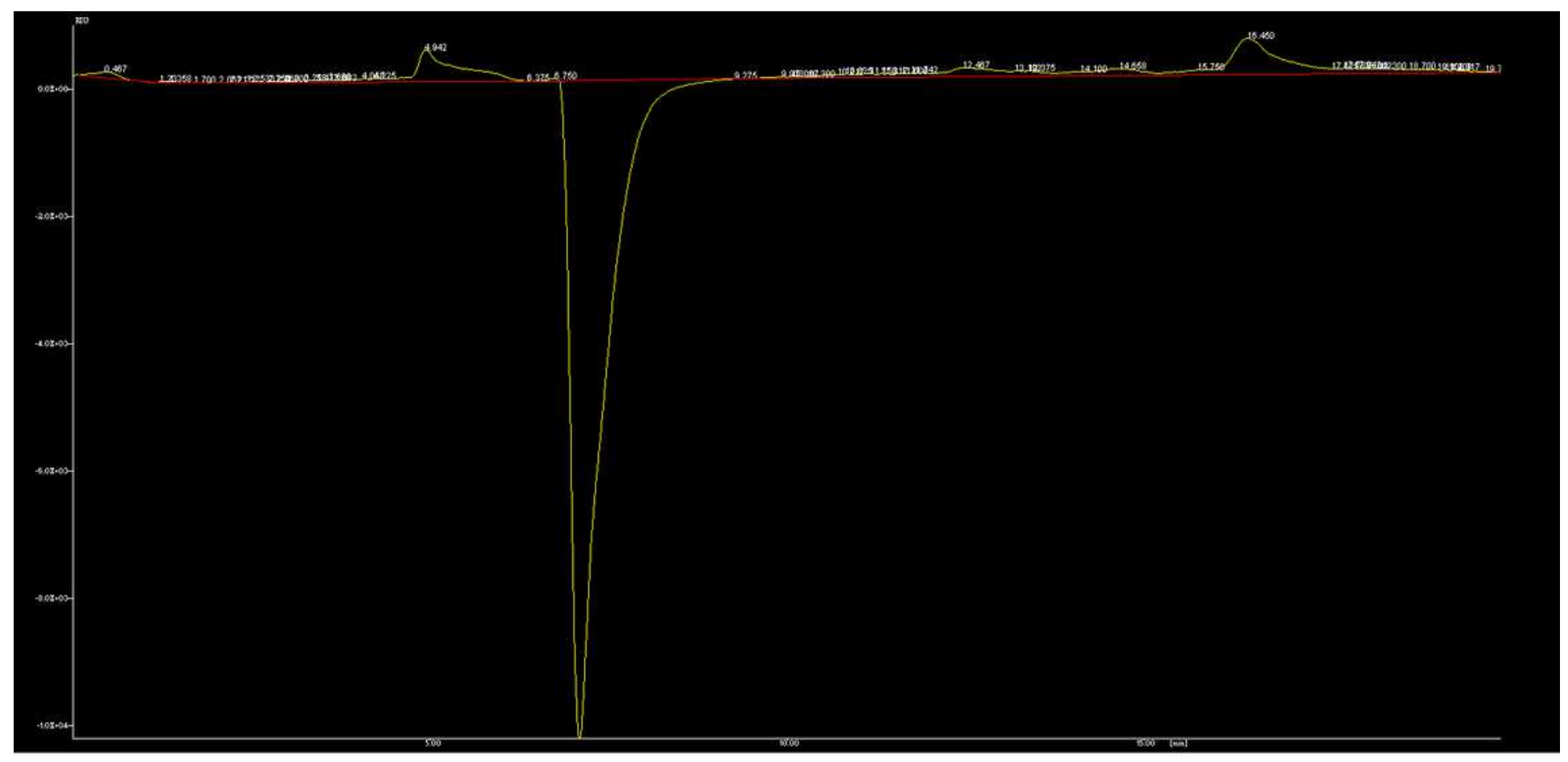

a

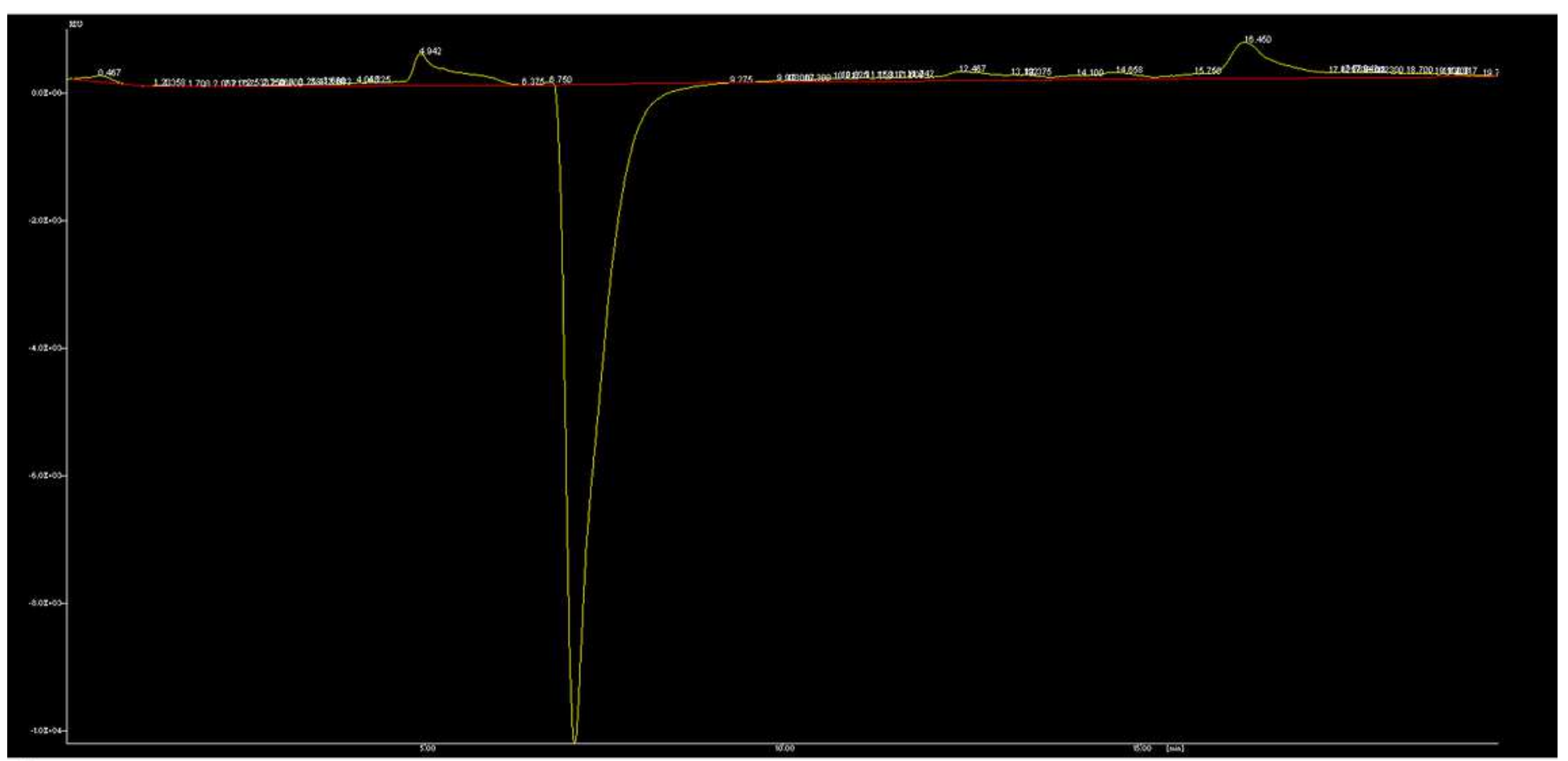

b

\section{Figure 3}

(a) : HPLC generated graph for fermentation using glucose from enzymatic hydrolysis (b): Zoom in ethanol curve from HPLC for fermentation using glucose from enzymatic hydrolysis

\section{Supplementary Files}


This is a list of supplementary files associated with this preprint. Click to download.

- GraphicalAbstractupdated.png

- Highlights.docx 